\title{
Use of Electronic Resources among Academics at the University of Maharshi Dayanand University Rohtak Haryana : A Study
}

\author{
Dharmender Singh ${ }^{1}$, Dharam Pal ${ }^{2}$ and Ram -Chander ${ }^{3}$ \\ ${ }^{1}$ Research Scholar, Dept of Library \& Information Science, \\ Singhania University, Pacheri Bari, Jhunjhunu (Raj.), India \\ ${ }^{2}$ Librarian, Department of Library \&Information Science Singhania University, \\ Pacheri Bari, Jhunjhunu (Raj.) India \\ ${ }^{3}$ Librarian, Department of Library \& Information Science \\ Aggrwal college Ballabgarh, Faridabad, Haryana, India
}

\begin{abstract}
This paper is an attempt to study the use of electronic information resources, the collection of print and electronic journals its awareness among the users, and the places where the users are accessing these resources. A total number of 120 users from the, postgraduate, research scholar and faculty members were selected and their response was obtained with the help of questionnaire. The findings show that users from all these categories were using e-resources; the awareness about eresources encourages users to use such resources to the maximum; and the users are using computer centre and hostels more for accessing the information. The impact of e-resources was visible from the decrease in number of printed journals in comparison to the increase in number of electronic journals. The use of e-journals has increased manifold. The printed material is being quickly replaced by the electronic resources.
\end{abstract}

Key Words: Case study, electronic journals, electronic information resources, usage of $e$ resources, printed journals.

\section{Introduction}

Information and communication technologies (ICTs) are seen as general-purpose forms of technology with applicability across a broad range of uses (Ashcroft \& Watts 2005; Katundu 2000; Ojedokun \& Lumande 2005; Powell 2002; Stilwell 2007). The application and integration of ICTs may be varied, depending on the specific uses to which they are put. They are therefore regarded as being applicable to specific industrial and professional sectors, such as libraries, banking, healthcare, and education. Academic libraries have benefited from the application of ICTs in information storage and retrieval, and in that context potential skills requirements on the part of users include familiarity with computer packages, the ability to use internet resources such as e-mail and edatabases, and information retrieval skills such as the ability to conduct Boolean or keyword searches.

When first introduced into academic libraries, ICTs were applied to carry out functions such as cataloguing, the creation of online public access catalogues (OPACs), acquisitions, circulation, and processes such as digitization (Levy et al 2003; Zainab, Abdullah \& Anuar 2004). This focus limited their application to control by the librarians and to the accessing of information resources within one's own library. Today the use of ICTs in academic libraries focuses more strongly on the users, the infrastructure, and the skills that users should possess in order to benefit from access to unlimited information resources. The importance of ICTs therefore lies more in their ability to facilitate increased access to information and to promote wider communication. This article deals more specifically with ICT infrastructure, ICT competencies, and the use of electronic resources. ICT infrastructure applies to specific components, including PC workstations for students, intranets and the internet, computer application packages, and connectivity. ICT competencies refer to the students' basic skills in the use of computers and the internet for information retrieval. 
Electronic resources, according to Hawthorne (2008), date back to the mid-1960s with the introduction of the machine readable catalogue (MARC), which was followed by online public access catalogues (OPACs). In the late 1960s bibliographic databases were developed, followed by CD-ROM databases in the late 1980s, online databases, and by web-based (internet) databases at the turn of the 21 st century, which also saw the introduction of electronic serials and electronic books. In this development timeline of electronic resources, the internet is the most popular form of ICT available today, and it has made the greatest impact on access for library users worldwide (earlier electronic resources were limited to singleuser access). The use of these internet-based electronic resources is examined in this article.

\section{Literature Review}

Ajuwon (2006) conducted a study of the physicians' use of the Internet for health information for patient care at the University College Hospital (UCH) Ibadan, Nigeria. The findings revealed that $98 \%$ of the respondents had used the Internet. A majority $(76 \%)$ accessed the Internet from cyber cafes. Ninety percent reported that they had obtained information from the Internet for patient care; of this number, $76.2 \%$ had searched a database.

Asemi (2005) did a case study of Medical Sciences University of Isfahan (MUI), Iran. The results of the study showed that all the respondents used the Internet frequently because all faculties had an Internet connection. It was revealed that the researchers of the university were getting quality health information and patient care through the Internet. Fifty-five percent of respondents searched for scientific health information through the Internet because the university library provided access to databases and online journals students and staff.

Nicholas, et al. (2003) conducted a study in the UK to examine the use of the web for health Information and advice. More than 1,300 people were surveyed. The study showed that $66 \%$ of the respondents accessed the Internet from home, $28 \%$ from work, and the remainder $(6 \%)$ used a combination of both work and home.

Okoye and Ejikeme (2011) affirmed the necessity of accessing needed information research, in enriching education and sharing of knowledge; since there is a critical need to make research results available to as many academics and elite class as possible. However, despite the inherent benefits, researchers into the use of electronic resources have examined constraints associated with the use of ICTs and e-resources.
Nigeria (Ondari-Okenwa 2004; Ashcroft and Watts, 2005; Adomi, 2005; Oduwole and Sowole, 2006; Watts and Ibegbulam, 2006). These include inadequate ICT skills among staff and users, low basic information literacy levels in the Nigerian population, prohibitive cost in developing countries to gain access to internet through cybercafé, inadequate ICT infrastructure and affordable online access. However in a, recent study of 117 faculty members on the use and user perception of $\mathrm{e}$ resources in Annamalai University.

Natarajan (2010) established that frequency of electronic resources was low despite its wide range availability. Identified constraints he further noted were: inadequate time, poor awareness, poor subject coverage, and slow downloading.

\section{E- Resource}

Electronic represent an increasingly important component of the collection building activities of libraries electronic resources refer to those materials that require computer access whether through a personal computer mainframe or handheld mobile device. They may either be accessed remotely via the internet or locally. Some of the most frequently encountered types are.

1. E-journals.

2. E-books.

3. Full-text databases.

4. Reference databases (biographies, dictionaries directories encyclopedias ect.)

5. Numeric and statistical databases.

6. E-images.

7. E- audio /visual resources.

Electronic resources whether acquired via purchase or license, free from the web, bron digital or multiple format materials ( $\mathrm{CD}-\mathrm{ROM}$ combined with a book) Electronic resources present a number of challenges not encountered with the selection and acquisition of traditional analog materials and it is advisable for the library to develop clear policies and processes for the selection and management of such resources. This will provide clarity to staff and ensure that electronic resources within the library are developed whit due consideration of cost, technical feasibility , licensing, access and preservation requirements, and constraints.

\section{Scope of the study}

This study is limited to the Faculty of Arts, University of MDU (Maharshi Dayanand University Rohtak). The university has five faculties. The Faculty of Arts is the largest, consisting of twenty departments in the social sciences and humanities. 


\section{Objective of the study}

1. To study about the adequacy of eresources in university libraries of Maharshi Dayanand University

2. To know about the importance of information content in e-resources over traditional sources.

3. To extract the different purposes of using e-resources.

4. To identity the challenges faced in the user of electronic information sources

5. To suggest suitable recommendations to provide the e-resources services of benefit of users.

\section{Methodology}

In the present study the questionnaire method has been adopted to collect information from the respondents. A well structured questionnaire covering all the facets of the topic has been prepared and distributed to Faculty of arts research scholars of various arts departments Maharshi Dayanand University Rohtak, Haryana

\section{Category of User.}

\begin{tabular}{|l|l|l|}
\hline Academics & 100 & $10 \%$ \\
\hline Students & 100 & $76 \%$ \\
\hline Researchers & 100 & $14.0 \%$ \\
\hline
\end{tabular}

A total of 120 questionnaires were distributed randomly to the MDU users, of which 100 were returned and used for analysis. Out of the 100 users, 10.0 percent are academics, 76.0 percent are students and 14.0 percent are researcher's shows user distributions of the respondents.

\section{Access to Internet.}

\begin{tabular}{|l|l|l|}
\hline Work & $100 \%$ & $3 \%$ \\
\hline Library & $100 \%$ & $20 \%$ \\
\hline Home & $100 \%$ & $30 \%$ \\
\hline Residential Hall & $100 \%$ & $28 \%$ \\
\hline Cyber Café & $100 \%$ & $19 \%$ \\
\hline
\end{tabular}

The findings showed that 3.0 percent users acknowledge access to internet at work place, 20.0 percent accessed internet at library, 30.0 percent accessed at home, 28.0 percent accessed internet at residential hall, and 19.0 percent users access at cyber café. Finally we can decide that, most of the users access internet at home and residential hall than other places.

\section{Access to Electronic Resources.}

\begin{tabular}{|l|c|c|}
\hline Every day & 100 & $40 \%$ \\
\hline A few Time every week & 100 & $20 \%$ \\
\hline At least once a week & 100 & $10 \%$ \\
\hline At least once a for night & 100 & $0 \%$ \\
\hline At least once a month & 100 & $10 \%$ \\
\hline
\end{tabular}

It was found that most of the 44.0 percent users access to electronic resources every day, 27.0 percent accessed electronic resources a few times every week, 17.0 percent accessed at least once a week, 3.0 percent accessed at least once a fortnight and 9.0 percent users accessed electronic resources at least once a month. Here we also see that, most of the MDU users used e-resources everyday, which is good sign for Maharshi Dayanand University

\section{Purpose of Using Electronic Resources.}

\begin{tabular}{|l|l|l|}
\hline Research & 100 & $6.0 \%$ \\
\hline Learning & 100 & $54.0 \%$ \\
\hline current information & 100 & $35.0 \%$ \\
\hline teaching & 100 & $5.0 \%$ \\
\hline
\end{tabular}

The MDU users use electronic resources for many purposes. According to the respondents, 54.0 percent users mostly used electronic resources for learning, 35.0 percent used e-resources for current information, 6.0 percent used electronic resources for research purpose and 5.0 percent used electronic resources for teaching purpose. Here, it is found that, more than half of respondents used eresources for learning purposes.

\section{Types of Electronic Resources Use.}

\begin{tabular}{|l|l|l|}
\hline Library Catalogue & 100 & $11 \%$ \\
\hline Bibliographic databases & 100 & $6 \%$ \\
\hline Electronic books & 100 & $21.0 \%$ \\
\hline Electronic journals & 100 & $62.0 \%$ \\
\hline
\end{tabular}

Analyzing the respondents replied, it has been found that, the majority of users 62.0 percent prefer to use electronic journals, second highest number of users 21.0 percent used electronic books, 11.0 percent users used library catalogue and the lowest 6.0 percent users used bibliographic databases. Here it is found that, most of the users use ejournals rather than library catalogue, bibliographic databases e-books 


\section{Conclusion}

This paper confirms that a large number of eresources are made available in MDU. This study reveals that, a majority of the users of MDU use eresources for their learning purpose. It was found that, e-resources materials in MDU are available and users are generally satisfied with these materials. Although MDU lacks of infrastructure facilities, the existing e-resources can fulfill user needs. Moreover, MDU should arranges more training programmes for users, appoint trained professionals with ICT skills and accommodated users opinions on subscribing new e-journals. With the growing popularity of e-resources, the following recommendations are made for improvement in the use of e-resources in Maharshi Dayanand University.

\section{Reference}

[1] Ashcroft, L \& Watts, C. 2005. ICT skills for information professionals in developing countries: perspectives from a study of the electronic information environment in Nigeria. IFLA Journal 31(1):6-12.

[2] Katundu, DR. 2000. African scientific information in international databases. Information Development 16(3):164-169.

[3] Ojedokun, AA \& Lumande, E. 2005. Cooperative electronic networks of academic libraries in southern Africa. Information Development 21(1):66-73.

[4] Powell, A. 2002. Supporting the revitalization of public libraries in Africa. Information Development 18(4):245-249.

[5] Stilwell, C. 2007. Library and information services in South Africa: an overview. IFLA Journal 33(2):87-108.

[6] Levy, P, Ford, N, Foster, J, Madden, A, Miller, $\mathrm{D}$, Nunes, MB, McPherson, $\mathrm{M} \&$ Webber, $\mathrm{S}$. 2003. Educational informatics: an emerging research agenda. Journal of Information Science 29(4):298-310.

[7] Zainab, AN, Abdullah, A \& Anuar, NB. 2004. Building online historical resources collaboratively: making the most of a digital library to reinforce ICT skills in Malaysia. Information Development 20(3):200-210.

[8] Hawthorne, D. 2008. History of electronic resources, in $\mathrm{Yu}, \mathrm{H} \&$ Breivold, $\mathrm{S}$ (ed),
Electronic resource management in libraries: research and practice. Hershey, PA: Information Science : 1-15.

[9] Katundu, DR. 2000. African scientific information in international databases. Information Development 16(3):164-169.

[10] Ajuwon, Grace A. 2006. Use of the Internet for health information by physicians for patient care in a teachinghospital in Ibadan, Nigeria. Biomedical Digital Libraries: 3-12.

[11] Asemi, Asefeh.2005. Information Searching Habits of Internet Users: A Case Study on the Medical Sciences University of Isfahan (MUI), Iran .2-1 .

[12] Nicholas, David. 2003 .The British and Their Use of the Web for Health Information and Advice: A Survey. Aslib Proceedings: 258-260.

[13] Okoye, M. O., \& Ejikeme, A. N. 2011. Open Access, Institutional Repositories, and Scholarly Publishing: The Role of Librarian in South Eastern Nigeria. Retrieved from http://unllib.unl.edu/LPP/okoye-ejikeme.htm

[14] Ondari-Okemwa, Ezra. 2004. Impediments to promoting access to global knowledge in subSaharan Africa. Library Management, 25(8/9): 361-375.

[15] Ashcroft, L., \& Watts, C. 2005. ICT skills for information professional in developing countries: Perspectives from a study of the electronic environment in Nigeria. IFLA Journal, 31(1): 6-12.

[16] Adomi, E. E. 2005. The effects of a price increase on cybercafés in Abraka, Nigeria: The bottom-line. Managing Library Finances, 18(2): 78-86.

[17] Oduwole, A. A., \& Sowole, A. O. 2006. Utilization and impact of The Essential Electronic Agricultural Database (TEEAL) on library services in a Nigerian university of agriculture. Program: electronic library and information systems, 40(2): 157-167.

[18] Watts, Chris, \& Ibegbulam, Ijeoma. 2006. Access to electronic healthcare information resources in developing countries. Experiences from the medical library, College of Medicine, University of Nigeria. IFLA Journal, 32(54).

[19] Natarajan, K. et al (2010). Use and user perception of electronic resources in Annamalai University: A case study. Ann. Lib.Inf. Stud., 57(1), 59-64. 